\title{
Multilateralism, Multipolarity and ASEAN: A Re-Appraisal
}

Prof. Y Yagama Reddy*

\begin{abstract}
The proliferation of regional organizations entailing overlapping membership of countries, though defy the spirit of regionalism, acts as laboratories for multilateral negotiations. Understandably, regional organizations serve as a tool towards the formation of multilateral bodies as well as conduits on the road to multilateralism. The regionalism-orientedmultilateralism assumes to be functional and action-oriented one. Yet, the support for the multilateralism and its principles has been shallow on account of the gap between the underestimated limitations vis-à-vis of overestimated potentials of multilateralism. In the midst of challenges that would render multilateralism obsolete, there are pertinent appeals made towards the end of reforming it. Contextual relevance would have it that ASEAN a typical regional organization moved onto the stage of multilateralism. Notwithstanding the implications of the ASEAN-based multilateral bodies, ASEAN perplexingly has met with challenges stemmed out of the process of emerging multilateralism 2.0, a more open rather flexible system than the state-centric classical multilateral organisations which signify a closed system. This paper seeks to examine the ASEAN's role in the multilateral architecture vis-àvis the multilateralism 2.0' driven by major powers and assess the need for ASEAN to get itself adapted to the transformation in the offing.
\end{abstract}

Keywords: Regionalism, Multilateralism, Multipolarity, ASEAN, ARF, ADMM plus, Southeast Asia, India, NORMS, Geopolitics

* Prof. Y Yagama Reddy is UGC Emeritus Fellow (2015-2017), Centre for Southeast Asian \& Pacific Studies, Sri Venkateswara University, Tirupati, India. 


\section{Multilateralism, Multipolarity and ASEAN: A Re-Appraisal}

\section{Introduction}

Multiplicity of regional groupings has become synonymous with overlapping membership of countries from both within and outside the region as well as certain glaring anomalies defying the spirit of regionalism. Understandably, that a single-region focus is inadequate has served as a stimulant for strengthening multilateral arrangements. At the same time, it is important to be borne in mind that the more states participate in the multilateral system; the more difficult it becomes to govern it. In reality, multilateral organisations are depicted as 'extensions of states doing those things that states cannot do on their own' (Klabbers, 2005, p. 278). Regional organizations acting as a tool towards the formation of multilateral bodies; yet, some individual states choose to play both the regional and multilateral cards simultaneously, as could be inferred from the proliferation of Free Trade Agreements between the countries. The effect of regionalism on multilateralism would have it that the regional organizations act as laboratories for multilateral negotiations as well as conduits on the road to multilateralism. Both regionalism and multilateralism are not ends in themselves and both are considered as vehicles to address the issues of global governance (Viswanathan 2015, p. 5). This attitude of the countries, though seemingly perplexing, points out the shortfall of the rule-based multilateral frameworks. This reminds that the regionalism-oriented-multilateralism has its focus on functional and action-oriented, rather inclusive multilateralism, in which the countries in the region together become equal partners to address challenges through voluntary and coordinated actions. The starting point of multilateralism is referred to the definition of Keohane (1990, p. 732) and its expansion by Ruggie (1993, p.11). To Keohane, multilateral arrangements are the institutions with 'persistent sets of rules' in a purely institutional (rather than normative) manner, while Ruggie looks at multilateralism as an institutional form as well as normative including behaviour on the basis of generalised principles of conduct.

In an insightful discussion on multilateralism as a facet of international relations, James Scott (Professor of Political Science, Texas Christian University) views multilateralism as a process of organizing relations between groups of three or more states, and as having comprised certain qualitative elements or principles that shape the character of the arrangement or institution. These principles, as elucidated by James Scott, encompass an indivisibility of interests among 
participants, a commitment to diffuse reciprocity, and a system of dispute settlement intended to enforce a particular mode of behaviour, and durability and influence (Scott 2015). To William H. Overholt, (President of the Fung Global Institute and a Senior Fellow at Harvard University's Asia Centre), the revival of multilateral negotiations becomes imperative, inasmuch as multilateralism heightens growth and reduces inequality (Overholt 2014). Even as being critical of overlapping web of multilateral institutions, Amitav Acharya (Professor of International Relations, UNESCO Chair in Transnational Challenges and Governance, and Chair of the ASEAN Studies Center, American University, Washington DC) subscribed to the notion of multiplex world to describe the emerging world order portraying a world of diversity and complexity (Henry et al 2013). Also worth consideration are the remarks of Anne Osborn Krueger (the World Bank Chief Economist from 1982 to 1986, and the first deputy managing director of the International Monetary Fund (IMF) from 2001 to 2006) that the support for multilateralism was "little more than a lip service," given the outward "wide support for the multilateralism and for the principle of multilateralism" (Krueger 2006). Ironically, it carries all along with it the incongruity: the US despises multilateralism, while China and Russia disguise as advocates and defenders of it.

The reality has it that it is not the controversy on the diplomatic procedure, but on the question of which principles, values and organizations should determine the international order. Understandably, there is gap between the underestimated limitations vis-à-vis of overestimated potentials of multilateralism. (Stiftung Wissenschaft und Politik 2020). Arguably, multilateralism is prone to face serious challenges in the 21 century, even though there is hardly any crisis to the fundamental principle of multilateralism. Of some relevance is the observation of Shoalin Yang, World Bank Managing Director and Chief Administrative Officer that "multilaterism really works: we owe it to the next generation to strengthen our commitment to it" (Robinson 2016). Taking cognizance of the multilateral system as being "fragmented, inefficient and out of date," East Asia Forum Editorial Board calls for reforming multilateral system (EAF Editorial Board 2020). Having given credence to the dynamics of multilateralism, the forthcoming discussion offers a deeper insight into the uneven disposition ASEAN multilateralism and its implications for Southeast Asia as well as ASEAN's role in the multilateral architecture in the context of transformation. 


\section{ASEAN a case in point of Multitudinous Multilateral Institutions}

The world has witnessed a significant increase in the number of multilateral organizations in the last few decades. The proliferation of multilateralism is at its best understood as the emergence of multitudinous multilateral arrangements or institutions. In its simple definition, multitudinous carries the meanings of: 'existing in great numbers,' 'consisting of a great number' and 'comprising many parts or elements.' Etymologically, the word multitudinous is of Latin origin (c.1600): multitudin- (stem of multitudo) multitude+-ous. It may also be deduced as multitude (gen. multitudinis), multitude+-ous (https://www.etymonline.com/ word/ multitudinous). Overwhelmingly, this word has multiple adjective usages, like numerous, many, considerable, countless, legion, infinite, abounding, abundant, innumerable, myriad, copious and manifold. The forthcoming discussion would adequately explain the rationale behind the emergence of Southeast Asia as an arena of multitudinous multilateral institutions in the last three decades since the end of Cold War.

\subsection{Southeast Asia, One-Region and ASEAN, One-Vision}

Known fact of Southeast Asia is the ubiquitous dissimilarity in socio-cultural milieu, identity, polity, colonial history among the post-colonial states of Southeast Asia which with no exception lacked any understanding of multilateral cooperation. Nonetheless, the nascent independent states of Southeast Asia embarked on evolving regional cooperation mechanisms. Though the first initiatives of ASA and MAPHILINDO turned into abortive experiments, their unstinted commitment to seeking greater strength in self-reliance and overcoming their problems was fructified in the form of Association of Southeast Asian Nations (ASEAN), the first ever indigenous organization established in August 1967. In tune with its underlined pledge to non-interference and non-confrontation, and consultation and consensus, ASEAN got itself well-adopted to its ASEAN Way, which has more often than not proved itself successful in the resolution of certain contentious issues. In the midst of harsh challenges, the long-felt dream of 'one-region-one vision' was realized with the evolution of ASEAN as a full-fledged regional organization (A-10) encompassing all the Southeast Asian countries. Appreciably, as could be gleaned from the tribute of Ponciano Intal Jr (a Senior Economist at the Economic Research Institute for ASEAN and East Asia), ASEAN "transformed an area of turmoil, antagonism and violence into a zone of cooperative peace and prosperity, and disparate 
economic backwaters into an increasingly integrated global growth powerhouse" (Intal $\mathrm{Jr}$ 2019). Equally noteworthy are the in-depth analytical studies of Amitav Acharya (Professor of International Relations at the American University, USA), and Kishore Mahbubani (Dean of the Lee Kuan Yew School of Public Policy, National University of Singapore) and Jeffery Sng (a writer and former diplomat based in Bangkok). A comprehensive account on ASEAN's future as a Security Community and Centrality in the regional security architecture by Amitav Acharya elucidates the norms and the feasibility of ASEAN way of conflict management in terms of ASEAN's non-interference doctrine and response to terrorism and other transnational challenges (Acharya 2014). In their book, The ASEAN Miracle: a Catalyst for Peace, commemorating $50^{\text {th }}$ anniversary of ASEAN, Kishore Mahbubani and Jeffery Sng discerned the factors for the ASEAN's success in bringing enduring peace and considerable prosperity (Mahbubani and Sng 2017). Even as making an objective assessment of the strengths and weaknesses of ASEAN through SWOT analysis, they have intriguingly advocated for the award of the Nobel peace prize to ASEAN which accomplished an "ecosystem of peace" in the highly diversified region in terms of geography, culture and troubled history. Contrary to the initial thinking of ASEAN as yet another ephemeral regional organization, ASEAN has emerged as one of the world's most successful collaborations and served as a model for other regions of the world; and the ASEAN Miracle is a befitting compliment to all the accomplishments to its credit.

\subsection{ASEAN-based Multilateral Mechanisms}

Certainly, ASEAN as an inter-governmental organization, unlike the supranational body of the European Union, functions on consensus, goodwill and cooperation of its 10 member states. During the last three decades since the termination of Cold War, the incentives of globalization have caused an impulsion for the evolution of a variety of new regional arrangements, distinctively in the Southeast Asian region. ASEAN-based regional networks have assumed significance in the context of almost totally devoid of multilateral bodies hinging on the other organizations of continental reach. Like many other multilateral bodies, ASEAN-centric regional bodies (ARF, ASEAN+3, ASEAN+1, ASEM, JACIK, and EAS have transcended the political regional boundaries and defied the basic tenets of region-forming factors and processes as well. These regional bodies, especially the trans-regional organizations, remind us of the factors of mathematical equations or the compounds produced out of chemical reactions. This is "the web of interlocking bilateral relationships (that) would lead to the 
multilateral level, within the framework of ASEAN," as described by J. Soedjati Djiwandono (Indonesian political analyst instrumental to found the Centre for Strategic and International Studies in Jakarta (Djiwandono 1997). The diverse new arrangements of ASEAN could effectively deal with an array of political and transnational concerns as well as a wide range of trans-regional issues as, for instance, public health and energy (EAS), security (ARF and ADMM-Plus) and trade (APEC and TPP). Undeniably, ASEAN-led multilateral bodies remain attractive and useful as well as retain their comparative advantages in the area of security for the countries concerned. In the context of the rapidly growing Southeast Asia's economy getting tied with the global economy and the region's geopolitical implications to the world's major powers, ASEAN could well manage its internal affairs and handle East Asian relations. Of much significance is the observation of Richard Stubbs, Professor of Political Science at McMaster University that ASEAN has played a leading role in building East Asia regional institutions, despite none of its members is a major economic and military power. But Richard Stubbs was quick to point that the ASEAN and its members need to refrain from playing a leadership role on all issues preoccupying the region, even as the major powers have conferred on ASEAN with freedom of regional institution building (Stubbs 2014). There is a positive view of ASEAN better understood from the captivating analysis of Kishore Mahbubani and Jeffrey Sng in their book, The ASEAN Miracle: a Catalyst for Peace, wherein they argued that the integration of ASEAN was largely accomplished by the ASEAN-based regional networks which have also linked the ASEAN members to the wider East Asia region (Mahbubani and Sng 2017). This form of multilateralism has become a conspicuous phenomenon through the participation of all or a few of the ASEAN-member-states leading to the formation of such regional bodies as APEC, TPP, IOR-ARC, GMS, BIMSTEC, MGC, Lower Mekong Initiative and BCIM.

\section{Lopsided Features of ASEAN Multilateralism}

ASEAN could survive o host of impediments for over two-and-half decades since its formation. The constellation of regional bodies, by virtue of overlapping, would subscribe to the convolutions and trust-deficit in the context of their interests getting clashed with others and the threats from certain intrinsic weaknesses and dissensions. JACIK (Japan-ASEAN-ChinaIndia-South Korea $=\mathrm{ASEAN}+3+1)$ is another multilateral initiative, considered as nothing more than a lateral expansion of ASEAN+3 or an antecedent to East Asia Summit $(\mathrm{ASEAN}+3+3)$, and hence derided as 'surplus to requirements.' Of relevance to the discussion 
the ASEAN Way which is often despised as an outmoded and under-performed one in the context of new form of global challenges. Knowing full well that ASEAN would hardly ever enforce any decision, the major powers wittingly support the ASEAN centrality. It turns to be blessing in disguise for the United States and China to act pretty much as they please without feeling any kind of restrictions on the part of the regional community (Tsvetov 2018). Further, China's growing economic and military power has made the member-states of ASEAN so much agitated as to think of strategies to counter its influence. Worth considering is the viewpoint of James Steinberg (professor at Syracuse University and a former U.S. Deputy Secretary of State) that the "effective multilateral arrangements allow them to resist China's divide and conquer strategy without being forced into an either-or choice of China and the U.S.” (Steinberg 2019).

It is the test of time, as cautioned by Chayut Setboonsarng (a policy analyst at the CIMB ASEAN Research Institute, for the ASEAN unity that calls for further regionalization and unstinted support for multilateralism in pursuit of the prosperity of nations (Setboonsarng 2012). ASEAN needs to overcome its own narrow self-interested approach towards regionbuilding and to be an honest broker desisting from the classical realist thinking of balancing role, by way of giving credence to the open regionalism and issue-led leadership. A sense of foreboding for the future of the ASEAN is ventilated by Ponciano Intal Jr (a Senior Economist at the Economic Research Institute for ASEAN and East Asia) that ASEAN is unlikely to maintain its centrality unless its leaders are prepared to take bold steps (Intal $\mathrm{Jr}$ 2019). This is a disparagement that finds some substance in the critical analysis of Mathew Davies (Head of the Department of International Relations in the Coral Bell School of Asia Pacific Affairs, The Australian National University):

ASEAN's own commitments are widely violated by the same members that created them.... This suggests that even the most traditional of ASEAN's aims, regional peace, is under threat. (The) ceremonies ... are moments of order in a sea of disorder, an emblem of trust amid so much mistrust. ASEAN's symbols and rituals are not a magic solution to regional ills nor do they guarantee future relevance. The symbols and rituals of ASEAN unity overlay, but do not replace, underlying disagreements and competition. ASEAN is a regional body built on sand, but symbols and rituals buttress it against collapse (Davies 2019). 


\subsection{Implications of Multilateralism for Southeast Asia}

It is known well that ASEAN has long taken pleasure in its 'driver's seat' of in East Asia multilateral bodies, as has been the case with the EAS which has been looked upon as an exemplary ASEAN-centred body. It was all about the early phase of ASEAN-led multilateralism. But, ASEAN needs to reconcile to the new form of global challenges demands; a compelling situation could be understood from the candid comments of Amitav Acharya that "ASEAN might have overestimated its capacity to assume the role of driver in the development of the ARF, ASEAN plus Three, and East Asia Summit. These burdens now challenge the sanctity of ASEAN's norms and the credibility of the ASEAN Way, including the doctrines of non-use of force and non-intervention" (Acharya 2014: 262). Most importantly, the power asymmetry and economic interdependence between China and Southeast Asian nations have made the smaller neighbours inevitably to sustain relationships with China that would weigh up higher than their territorial and resource claims. This was quite baffling that could be gauged in the context of the judgement of the UNCLOS tribunal on 12 July 2016 (PCA Press Release 2016) that ruled out the legal basis for any Chinese historic rights within the nine-dash line. The case in point is that the South China dispute has exposed the divisions among the ASEAN member states rather testifying to the erosion of ASEAN unity (Davis 2016). Apparently, Beijing has got succeeded to break ASEAN's always faltering unity on the South China Sea. The purported statement that "the ASEAN was not the venue to resolve sovereignty claims over the South China Sea" pointed out lack of strong and coherent response from ASEAN which, as reported in the Dailyhunt (2017) e-paper, agreed to China's terms for negotiations, just to avoid angering China.

It was about the same time that the multilateral cooperation gets disrupted by the traits of bilateral cooperation such as RTAs, FTAs and PTAs, when a few of the member states play both the regional and multilateral cards in tandem. Of much concern has been "the tendency of countries to place their own short-term interests ahead of their systemic interests in the multilateral system," lamented Anne Osborn Krueger, who further deplored that "the proliferation of PTAs and the continuing absence of a multilateral regime governing capital flows are both glaring and dangerous departures from multilateral principles (Krueger 2006). This disorder would have impelled Evan A. Feigenbaum, Vice Chairman of the Paulson Institute, located at the University of Chicago who also served the US Department of State. 
(Henry et al 2013) long time back in 2013 to lament that the Asia's major multilateral institutions to face the prospect of becoming almost irrelevant to practical problem solving. Former Ambassador, Ministry of External Affairs, Government of India, T. P. Srinivasan, was also sceptical of the multilateral cooperation as being impinged by the bilateral relations among neighbours (Srinivasan 2017). Even as multilateralism has carved a niche for itself in Asia's international relations, the non-ASEAN-members tend to far outweigh the ASEAN. It is not to be altogether discarded that the proliferation of regional bodies is akin to the European alliance systems preceding the First World War; and it is feared that Southeast Asia would meet the same fate as the Balkan states in the $19^{\text {th }}$ century as if being qualified for the title of "Balkans of the East."

\subsection{Varied Approaches of Major Powers to ASEAN Multilateralism}

Apropos of the current discussion are the differential approaches of some of the major powers. Not surprisingly, China looks at multilateralism as a part of its efforts to change the region to toe the line of its interests and values; and China thus resorts to exercising "its growing influence to divide members of regional institutions such as ASEAN, weakening collective leadership on important issues like the South China Sea as well as to cater more to its interests and limit the extent of the United States' influence" (Wood op.cit.). In the event of Shanghai Cooperation and Organization (SCO) formalizes a regional identity similar to that of the ASEAN, assertive behaviour in the South China Sea has stirred up among the ASEAN member-states an element of suspicion how an economically strong and militarily powerful China might act in the future (Sukma 2009). In the context of ASEAN's growing economic dependence on China, many ASEAN leaders wish to have China's new initiatives launched in the region (Kung 2015). Implicitly, the South China dispute has exposed the divisions among the ASEAN member states rather testifying to the erosion of ASEAN unity (Davis 2016). It was about the same time that the ASEAN countries have also been equally conscious of the deeper Sino-US strategic competition that could possibly undermine its unity (Supriyanto 2016).

The worst fear may likely to turn out; the Trump administration's commitment to its path of abandoning Asia's multilateral organizations would be tantamount to empowering China (Steinberg 2019). But, interestingly, some of the US allies look for multilateralism as part of their broader strategy to sustain the prevailing regional order. Foremost of them is Australia 
which strongly favoured multilateral institutions as "the best way to "preserve peace and curb excessive use of power" (Wood op.cit.). Given the security relations with Southeast Asia as a prelude to shape Indo-Pacific security architecture, the Australian Defence White Paper (2013) emphasizes the significance of Southeast Asia's stability and peace (Santikajaya 2013). The Australia's argument favouring ASEAN to "provide a more united and determined front towards China" was justified by none other than John McCarthy who served as Australian Ambassador to seven countries including the US, Indonesia, Japan and India (McCarthy 2016).

It is of much significance that the ASEAN centrality in the political and security architecture of the Indo-Pacific region" has also received the qualified support from the India-JapanAustralia trilateral dialogue (Roche 2017). Toeing the well-acknowledged ASEAN centrality by India-Japan-Australia, all the 10 leaders of the ASEAN-member-states ${ }^{(\mathbf{I})}$ appreciably recognized India's growing stature in ensuring regional peace and stability in the wake of rising tensions between China and a number of countries of the grouping over the South China Sea dispute (India Defence News 2018). Later in June 2018 in his keynote address at the ShangriLa dialogue of the International Institute for Strategic Studies (IISS) in Singapore, Prime Minister Narendra Modi delineated the spirit and purpose of India's 'free, open, inclusive' Indo-Pacific (FOIIP) policy which regarded ASEAN as the "core of the Indo-Pacific region" (Roy-Chaudhury 2018).

\section{Multilateralism Transforming towards Multipolarity}

Debatably, multilateralism emerges as an almost essential form of international diplomacy; interestingly, a number of scholars have documented the rise and spread of multilateralism as a social form in world politics (Finnermore 2005, p. 194). A myriad of agencies and institutions in the present day multilateral system have been created during 1945-2000. With the cessation of the bipolar rift of the Cold War era, the unipolar frame with the US as the lonely superpower and the dominant state remains stable, and even the G7 states keep on to maintain their primacy, of course, with a little bit of anxiety and defensive stance (Wade 2011). Be that as it may, the post-Cold War globalization has led the world more interdependent than ever before. As an outcome of infiltration of functional market into national economies, the contours of regionalism and multilateralism have undergone transformation (Viswanathan 2015, p.4). About the same time, there is a discernible shift to multipolarity that has stirred up such terms as 'nonpolar' world, 'neopolar' world, 'interpolarity' and 'regiopolarity,' as could be learnt 
from a lively discussion on the transformation of multilateralism (for an overview, see Langenhove 2010, pp.4-5). The multitude of regional cooperative mechanisms is at the present looked upon as a prelude to the emergence of multi-polarity that is expected to foster global level stability.

\subsection{History of Multilateralism}

Even as the term, multilateralism, is of relatively recent origin, as a form of cooperation among the states it can be traced back to the Westphalia world order which laid its entire accent on the concept of nation-states. The world order based upon a state system is thus indubitably considered as an unintended consequence of Westphalia (Valaskakis, 2001, p. 48). Even so, modern multilateralism has its origins traced back to the 1815 Vienna Congress that led to the emergence of the Concert of Europe. Besides being a limited form of cooperation and devoid of an institutionalized framework, the Concert of Europe was based on the voluntary collaboration of major powers. The two Hague conferences of 1899 and 1907, which brought together representatives of 42 states, are reckoned as a new milestone in the development of multilateralism. Industrial revolution provided an outline for technical multilateralism leading to the formation of 'bureaus' and 'international unions' that facilitated to frame rules in the common interest (for an outline, see https:// multilateralism 100.unog.ch/node/122). In the context of limitations of the states to undertake all activities and differential powers among the states, multilateral institutions turned to become the appendages of the states. But, multilateralism is above the concerted action of some partners. Thus, besides being functional in nature, rise of multilateralism is also spurred by ideas, identities, norms, and values, often coupled with power. Consequent upon the failure of League of Nations, the modern system of multilateralism had its basis in the World War II, when Franklin Roosevelt visualized "a single organisation at global level that would bring all states together in order to maintain international peace and security; develop international cooperation in solving common economic, social and cultural problems; and promote and encourage human rights and fundamental freedoms (Jolly et al 2005). The UN Charter, which came into existence in June 1945, is reckoned an important milestone in the history of multilateralism (Langenhove 2010). The UN multilateral framework of par excellence for 75 years has witnessed horizontal expansion (from 51 in 1945 to 193 as of now) as well as vertical growth through the participation of new actors other than sovereign states. If the UN has accomplished several tangible results testifying to the 
credibility of UN multilateralism, the challenges and criticism have warranted the UN to adapt to the changing realities of the world.

In order to surmount the predicament, the traditional multilateralism, much dependent on the input of states, needs to adapt to the changes in the context of global problems such as climate change, proliferation of weapons of mass destruction. Admittedly, both the notions of multilateralism-- normative concept (idealism) and practice (realism) -- are receptive to changes. Of much relevance to this context is to take note of the ideals and practices of multilateralism that are undergoing transformation underscoring the need for moving away from industrial approach into information age. There has been an impression gained that the functioning of the rule-based multilateral system is short of the expectations. In the place of the role of governments as singular actor, this is of course a new paradigm of collaboration between governments at different levels (including subnational governments) as well as between governments with all other relevant (non-governmental) actors in society, what is described as Multilateralism 2.0 implying the diversification of multilateral organizations. This articulates reliance on alternative forms arrangements that are trans-governmental, multi-level, and multi-stakeholder; and thus depends on innovative partnerships between states and nonstate actors, both private and public (Patrick 2015). It is about the same time feared that the national sovereignty is feared threatened by the supranational institutions; and in some cases, sub-national entities seldom trespass the sovereign state in pursuit of having their own direct relations at the regional or global level. Simply, it is the gradual erosion of state sovereignty. Unlike the state-centric classical multilateral organisations which signify a closed system, the emerging Multilateralism 2.0 is more open rather a flexible system that gives allowance to certain dimensions of the actors. If given credence to the second law of thermodynamics that the entropy of an isolated system always increases, the closed system is logically subject to the changes rather disorder. If multilateralism is evolving towards a more open system, as pointed at earlier, multipolarity is the logical corollary of the shift from unipolarity. There is discernible change also noticed in the authority and influence within the other multilateral organizations like the G20, the World Bank and the IMF (Wade 2011). This transformation from Multilateralism 1.0 to Multilateralism 2.0 obviously seeks all actors concerned to shape it and adapt to it. A more far-reaching concept than Multilateralism 2.0 is 'new multilateralism' that mulls over a trend towards multipolarity (Langenhove 2010, p.6-7); and over a period of time, multipolarity is would prove to be the only firm guarantor of a sustainable and fairer multilateralism. Luk Van Langenhove further argues that the regional organizations themselves 
need to adjust to the reality of multilateralism 2.0; and "the idea of multi-regional world needs to be supported and promoted by civil society. As long as this is not the case, old habits and organizational structures will not change, and the world will not become a more secure place to live in" (Langenhove 2011, p.7).

\subsection{India vouching for N.O.R.M.S.}

Having been a resolved adherent of multilateralism, India has also firmly believed that the path to achieve sustainable peace and prosperity is through multilateralism. Presumably, independent India would have considered multilateralism as an option for protecting and projecting national interests. India's commitment to upholding multilateralism was reiterated in January 2019 by the External Affairs Minister Sushma Swaraj (The Quint/ Dailyhunt 2019). Alongside, India favoured a "reformed multilateralism with a reformed United Nations at its center (to) meet the aspirations of humanity" (PM's Address 2017). In his video address on 21 September 2020 to the high-level meeting of the UN General Assembly that has commemorated the $75^{\text {th }}$ anniversary of the United Nations, the Indian Prime Minister renewed his call for a reformed multilateralism "that reflects today's realities, gives voice to all stakeholders, addresses contemporary challenges and focuses on human welfare." In the context of India's election as non-permanent member of the powerful UN Security Council for a two year term beginning January 1,2021, India's priorities for its tenure on the Security Council find 'resonance' in the Declaration that echoes New Delhi's call for strong mandate against terrorism, reformed multilateralism and inclusive development. India's overall objective during its tenure in the UN Security Council will be the achievement of N.O.R.M.S - a New Orientation for a Reformed Multilateral System. Justifiably, India's multilateral approach is "not obstructionist nor is it driven by a desire to impede multilateral efforts to address salient global challenges" (Nachiappan 2020). While launching the brochure that outlined India's priorities and approaches as it sought another term on the Security Council, the Indian External Affairs Minister S Jaishankar on $5^{\text {th }}$ June 2020 has noted a "widespread concern at the inadequacy of the existing multilateral institutions to deliver results or meet new challenges," and felt the "need to promote greater cooperation in multilateral institutions" (https://www.mea.gov.in/Images/amb1/ INDIAUNSC.pdf). The External Affairs Minister also asserted that India's overall objective during the fresh tenure in the UN Security Council will be the achievement of N.O.R.M.S (Raj 2020). Reformed multilateralism, as one of India's priorities, must reflect the contemporary realities to be more effective. If the remarks of Anne 
Osborn Krueger that the "support for multilateralism is little more than lip service" (Krueger 2006) are of any indication, India's commitment to achieving N.O.R.M.S. is rather justifiable.

\subsection{ASEAN in the context of Contested Multilateralism 2.0}

For all the pros and cons of multilateralism vis-a-vis global challenges, multilateralism offers better opportunities for dealing with complex tasks and it also legitimizes the results achieved that would be made sustainable (Stiftung Wissenschaft und Politik 2020). All the more important for effective multilateralism is the attitude of parties in terms of sharing a genuine interest in sustainable results, willingness to compromise over the demands and expectations of the issue/s and willingness to the principle of diffuse reciprocity by giving credence to the notion of benefits outweighing the interim shortcomings. Should the spirit and purpose of multilateralism be sustained, it is high time for ASEAN to assess the relevance of ASEAN Way and also for other non-ASEAN members in a raft of ASEAN-based bodies to make introspection of their commitment to the collective participation.

A new concept of 'contested multilateralism 2.0' has begun to gain prominence; consequently, the ASEAN's role in the multilateral architecture has begun to face up to the challenges from the multilateralism 2.0' driven by major powers and proliferation of non-ASEAN-centric minilateral arrangements. In the context of high strategic uncertainty and high economic interdependence after the 2008 global financial crisis in the Asia-Pacific, the institutional building efforts by an emerging constellation by of major powers and immediate neighbours have fructified into dominant global scenario. Even as underscoring the importance of multilateralism and the role of international institutions, Australian Foreign Minister Marise Payne pointed out that 'multilateral institutions are experiencing unprecedented strain from a new era of strategic competition' (Wood 2020). There has also been a budding impression that the conventional ASEAN conflict-management methods ceased to be effective; as consequence, new conflict management patterns and trends tend to gain ascendancy, as could be well discerned from a study on the approaches conflicts in Southeast Asia from a conflictmanagement perspective (Oishi 2016). Unlike the ASEAN-led 'multilateralism 1.0' of the 1990s, this wave of multilateralism has been initiated by other powers, such as the US, China, Japan, Australia and South Korea (He 2019). This is what Nick Bisley called as "sublimated form of contestation" that would weaken the policy impact of existing institutional efforts (Bisley 2019). Kilian Spandler, an eminent researcher at the School of Global Studies of the 
University of Gothenburg, Sweden, in his study on the normative foundations of ASEAN and EU rightly pointed out that the organizational stability and change are shaped by the context of regional foundational norms; yet, the multifarious and vibrant nature of such norms would make the breeding ground available for contestation and, at times, institutional sclerosis and failure (Spandler 2019).

This is a predicament due in large part to the changing attitudes of the non-ASEAN-powers which have for long engaged with ASEAN in the absence of alternatives. Known fact was the period of prosperity enjoyed by East Asia until the turn of last century; subsequently, stability has paved the way to uncertainty and insecurity manifesting in shifting balance of interests and power (Bisley 2019:225). If non-ASEAN powers become successful in creating credible alternatives, Sarah Teo argues, ASEAN's centrality in multilateralism would get weakened before long, especially in context of the US disdain for multilateralism including the ASEANcentric forums. Mention may be made of the Quadrilateral Security Dialogue (involving Australia, India, Japan and the US and the Lacang-Mekong-Cooperation (Cambodia, China, Laos, Myanmar, Thailand and Vietnam) which may likely bring about concerns over the ASEAN-centric multilateral architecture (Teo 2020).

\section{Notes}

(I) Marking 25 years of India-ASEAN ties, India-ASEAN Commemorative Summit was held in New Delhi on 25 January 2018, attended by all the 10 ASEAN leaders who were exceptionally the invited chief guests at the Republic Day celebrations on $26^{\text {th }}$ January.

\section{References}

Acharya, Amitav, 2014. Constructing a Security Community in Southeast Asia: ASEAN and the Problem of Regional Order, $3^{\text {rd }}$ edition, Routledge, New York, 314 p.

Bisley, Nick, 2019. "Contested Asia's 'New' Multilateralism and Regional Order," The Pacific Review, vol. 32, No.2, pp. 221-231.

Dailyhunt, 2017 (August 07). "South China Sea: Beijing diplomatically scores over ASEAN," m.Dailyhunt.in, at < http://m.dailyhunt.in/news/india/english/newsbytes-epaper-newbyt/ south+china+sea+beijing+diplomatically+scores+over+asean-newsid-71404802?ss> (Accessed 08 August 2017). 
Davis, Malcolm, 2016 (May 12). "What does Rodrigo Duterte mean for South China Sea tensions?" Australian Strategic Policy Institute, at <https://www.aspistrategist. org.au/ whatdoes-rodrigo-duterte-mean-for-south-china-sea-tensions/> (Accessed 08 January 2017).

Davies, Mathew, 2019 (12 January). "Why Southeast Asia still bothers with ASEAN," East Asia Forum, <https://www.eastasiaforum.org/2019/01/12/why-southeast-asia-still-botherswith-asean/> (Accessed 12 January 2019).

Dutta, Ashok K., 1985. Southeast Asia: Realm of contrasts, 3rd edn., Westview press: Boulder.

Djiwandono, J. Soedjati, 1997. "The Strategic Dynamics of Post-Cold War in Southeast Asia," pp. 170-180; in Denny Roy (ed.), The New Security Agenda in the Asia-Pacific Region, Macmillan Press Ltd.: London, 183p.

EAF Editorial Board, 2020 (21 September). "The multilateral system: use it, or lose it," East Asia Forum, https://www.eastasiaforum.org/2020/09/21/the-multilateral-system-use-it-orlose-it/\#more-299844 (Accessed 21 September 2020).

Finnermore, Martha, 2005. "Fights about rules: the role of efficacy and power in changing multilateralism," Review of International Studies, vol. 31, pp. 187-206.

Fisher, Charles A., 1966. Southeast Asia: A Social, Economic and Political Geography, Methuen \& Co.: London.

He, Kai, 2019. "Contested Multilateralism 2.0 and Regional Order Transition: Causes and Implications," The Pacific Review, vol. 32, No.2, pp. 210-220.

Henry, Ken, Hu Shui, Evan A. Feigenbaum and Amitav Acharya, 2013 (14 August). "“Multiplex world': steps towards a new global order,"” East Asia Forum, at <http:// www.eastasiaforum.org/2013/08/14/multiplex-world-steps-towards-a-new-global-order/> (Accessed 20 July 2020).

https://www.mea.gov.in/Images/amb1/INDIAUNSC.pdf

India Defence News, 2018 (27 January). "ASEAN Leaders want India to be Assertive in IndoPacific Region," at <http://www.indiandefensenews.in/2018/01/asean-leaders-want-india-tobe-more.html> (Accessed 31 January 2018).

Intal Jr, Ponciano, 2019 (24 February). "Time for bolder steps from ASEAN," East Asia Forum, at <http://www.eastasiaforum.org/2019/02/24/time-for-bolder-steps-from-asean/ > (Accessed 25 February 2019).

Jolly, Richard, Louis Emmerij, and Thomas G. Weiss, 2005. The Power of UN Ideas: Lessons from the first 60 years: a Summary of the Books and Findings from the United Nations Intellectual History Project, United Nations Intellectual History Project: New York.

Keohane, Robert O., 1990. 'Multilateralism: An Agenda for Research,' International Journal, vol. 45, Issue XLV, pp. 731-764. 
Klabbers, J., 2005. 'Two Concepts of International Organisations,' International Organisations Law Review, vol. 2, pp. 277-293.

Krueger, Anne Osborn, 2006 (19 September). An Enduring Need: The Importance of Multilateralism in the 21st Century, Speech at the Annual meetings of the IMF and the World Bank: Singapore.

Kung, Phoak, 2015 (April 03). "Don't blame Cbodia for ASEAN inaction on South China Sea," East Asia Forum, at < http://www.eastasiaforum.org/ 2015/04/03/dont-blame-cambodia-forasean-inaction-on-south-china-sea/> (Accessed 20 June 2015).

Langenhove, Luk Van, 2010 (04 October). "The Transformation of Multilateralism Mode 1.0 to Mode 2.0," Global Policy-Wiley Online Library, at <https://onlinelibrary.wiley. com/ doi/full/10.1111/j.1758-5899.2010.00042.x> (Accessed 07 September 2020).

Langenhove, Luk Van, 2011 (31 May). "Multilateralism 2.0: The transformation of international relations," United Nations University, at http://unu.edu/ publications/ articles/multilateralism-2-0-the-transformation-ofinternational-relations.html (Accessed 07 September 2020).

Mahbubani, Kishore and Sng, Jeffrey 2017. The ASEAN Miracle: A Catalyst for Peace, National University of Singapore Press, 286 p.

McCarthy, John, 2016 (March 17). Australia and the South China Sea," Australian Strategic Policy Institute; at <https://www.aspistrategist.org.au/australia-and-the-south-china-sea/>, Accessed 08 January 2017.

Nachiappan, Karthik, 2020 (15 January). "Redirecting Multilateralism: Will India Seize the Opportunity?" Heinrich Böll Stiftung: The Green Political Foundation; at <https:// www. boell.de/en/2020/01/15/redirecting-multilateralism-will-india-seize-opportunity> (Accessed 15 August 2020).

Oishi, Mikio (ed.), 2016. Contemporary Conflicts in Southeast Asia: Towards a New ASEAN Way of Conflict Management, Springer: Singapore, 205 p.

Patrick, Stewart, 2015 (08 July). Multilateralism à la Carte: The New World of Global Governance, No.22, Valdai Discussion Club: Moscow, at < https://valdaiclub. com/ a/ valdaipapers/valdai_paper_22_multilateralism_la_carte_the_new_world_of_global_governance/> (Accessed 04 July 2017).

PCA Press Release, 2016 (July 12). The South China Sea Arbitration, Permanent Court of Arbitration: The Hague, Netherlands, 11 p., at <www.pca-cpa.org>

PM's Address, 2017 (17 July). "India firmly believes that the Path to achieve Sustainable Peace \& Prosperity is through Multilateralism: PM," at <https://www.narendramodi.in/ pm-saddress-in-ecosoc-commemoration-of-uns-75th-anniversary-550579> (Accessed 08 December 2018). 
Raj, Yashwant, 2020 (18 June). "India reaffirms commitment to reformed multilateralism' after winning UNSC seat," Hindustan Times (Washington), at <www.hindustantimes.com/indianews/india-reaffirms-commitment-to-reformed-multilateralism-after winning-unsc-seat/story1CRTMxCbVJclosdbPZY95M.html> (Accessed 18 August 2020).

Robinson, Zubedah, 2016 (10 December). Multilateral cooperation needed to solve world's biggest challenges today, The World Bank Group, at http://blogs.worldbank.org/ voices/multilateral-cooperation-needed-solve-world-s-biggest-challenges-today (Accessed 01 July 2017).

Roche, Elizabeth, 2017 (17 November). "Need to shed Cold War mentality for closer IndoPacific ties: China," live mint, at <http://www.livemint.com/Politics/ ZsRg Dte 3805 wnhONMEAK7I/Need-to-shed-Cold-War-mentality-for-closer-IndoPacific-ties.html> (Accessed 24 December 2017).

Roy-Chaudhury, Rahul, 2018 (07 August). "Modi spells out free, open, inclusive Indo-Pacific policy," International Institute for Strategic Studies (IISS) Analysis, at <https://www. iiss.org/ blogs/analysis/2018/08/modi-free-open-inclusive> (Accessed 19 September 2018).

Ruggie, John Gerald, 1993. Multilateralism Matters: The Theory and Praxis of an Institutional Form, Columbia University Press: New York.

Santikajaya, Awidya, 2013 (29 June). "Challenges to ASEAN as an Indo-Pacific security connector," East Asia Forum; at <http://www.eastasiaforum.org/ 2013/06/29/ challenges-toasean-as-an-indo-pacific-security-connector/> (Accessed 05 April 2015).

Scott, James, 2015 (13 October). "Multilateralism: International Relations," Britannica, https://www.britannica.com/topic/multilateralism (Accessed 15 August 2020).

Setboonsarng, Chayut, 2012 (20 December). "Multilateralism is key to ASEAN's success," East Asia Forum, at <http://www.eastasiaforum.org/2012/12/20/multilateralism-is-key-toaseans-success/> (Accessed 5 August 2013).

Singh, Yoshita, 2020 (22 September). "On UN's 75th anniversary, Modi calls for Reformed Multilateralism," Rediff.com, at https://www.rediff.com/news/report/un--75-modi-calls-forreformed-multilateralism/20200922.htm> (Accessed 22 September).

Spandler, Kilian, 2019. Regional Organizations in International Society: ASEAN, the EU and the Politics of Normative Arguing, $1^{\text {st }}$ edition, Palgrave Macmillan: London, 205p.

Sreenivasan, T.P., 2017. "Multilateral Cooperation: Emerging Scenario," (pp. 24-28), in Jayachandra Reddy, G., India's Multilateral Engagement: Opportunities and Challenges, UGC Centre for Southeast Asian \& Pacific Studies, Sri Venkateswara University: Tirupati, 326 p. 
Steinberg, James, 2019 (21 November). "By abandoning Asia's multilateral organizations, US empowers China," Nikkei Asian Review, at <https://asia.nikkei.com/Opinion/By-abandoningAsia-s-multilateral-organizations-US-empowers-China> (Accessed 26 July 2020).

Stiftung Wissenschaft und Politik, 2020 (March). Multilateralism: Variants, Potential, Constraints and Conditions for Success, SWP Comment 2020/C 09, German Institute for International and Security Affairs, at <httpss://www.swp-berlin.org/ 10. 18449/ 2020C09/ (Accessed 15 August 2020).

Sukma, Rizal, 2009. "Indonesia-China Relations: The Politics of Reengagement," Asian Survey, vol. 49, No. 4, July-August, pp. 595-600.

Supriyanto, Ristian Atriandi, 2016 (March 26). "What Australia's stance on the South China Sea means for Southeast Asia," East Asia Forum, at <http://www. eastasiaforum. org/? p= 50014>, Accessed 30 December 2016.

Teo Sarah, 2020 (7 January). "Strengthening the ASEAN-centric multilateral security architecture," East Asia Forum, at <https://www.eastasiaforum.org/?p=226376> (Accessed 02 February 2020).

The Quint / Dailyhunt, 2019 (15 January). "India for improved multilateralism with focus on Indo-Pacific," at <https://m.dailyhunt.in/news/india/english/the+quint-epaper-quint/ india+for+improved+multilateralism+with+focus+on+indo+pacific-newsid-1063402\% E2\%80\%A6> (Accessed 15 April 2019).

Tsvetov, Anton, 2018 (27 September). "Russia and Multilateral Diplomacy in East Asia," Russian International Affairs Council, at < https://russiancouncil.ru/en/analytics-andcomments/analytics/russia-and-multilateral-diplomacy-in-east-asia/ > (Accessed 14 August 2020).

Valaskakis, K., 2001. 'Long-Term Trends in Global Governance: From "Westphalia" to "Seattle," pp.45-66, in Governance in the 21st Century: Power in the Global Knowledge Society, Organization for Economic Cooperation and Development: Paris, 218p.

Viswanathan, H.H.S., 2015 (March). "The Changing Contours of Regionalism and Multilateralism in a Globalised World," ORF Issue Brief \#89, Observer Research Foundation: New Delhi.

Wade, Robert H., 2011. "Emerging world order? From multipolarity to multilateralism in the G20, the World Bank, and the IMF," LSE Research Online Documents on Economics 38603, London School of Economics and Political Science, LSE Library, at https://ideas.repec.org/p/ehl/lserod/38603.html (Accessed 07 September 2020).

Yagama Reddy, Y., 2004 (July-December). "Geographical Causation in Southeast Asian History,” Journal of Contemporary Asia and Europe, vol.1, No.2, pp. 81-97. 
Yagama Reddy, Y., 2005 (spring). "The Fossilized Indian Culture in Toponyms and the Enigmatic Etymology of the Term: Southeast Asia," The Asianists' Asia (Paris), volume IV.

Yagama Reddy, Y., 2012 (December). "Geographical Pivot of Indian Ocean and the Scope for both Regional Cooperation and Geopolitical Context," Journal of Indian Ocean Studies, vol. 20, No.3, 2012, pp. 387-405.

Yagama Reddy, Y., 2012 A. "Geo-economic Imperatives vis-à-vis Geopolitical Rumblings in the Asia-Pacific Region", in Ganganath Jha and Vibhanshu Shekhar (eds.), Rising Indian the Changing Asia-Pacific, Pentagon Press: New Delhi, pp. 44-53.

Yagama Reddy, Y., 2018 (November). "India's Perspectives of SAGAR Concept and FOIIP Policy: Prospects manifest in Primacy of India's Diplomacy as much as Geographical Predisposition," World Focus (Special Issue: India's foreign Policy Series-1), vol. XXXIX, No.11, pp.25-31.

Yagama Reddy, Y., 2020 (August-September). "Implications of Multitudinous Multilateral Institutions for Southeast Asia," Electronic Journal of Social and Strategic Studies, Vol.1, Issue 1, pp. 82- 104.

Wood, Bradley, 2020 (15 July). "Australia's vision of leadership in the Indo-Pacific," East Asia Forum, at <https://www.eastasiaforum.org/2020/07/15/australias-vision-of-leadershipin-the-indo-pacific/\#more-271690> (Accessed 17 July 2020). 